\title{
KONTRIBUSI KOMPETENSI PEDAGOGIK DAN MOTIVASI BERPRESTASI TERHADAP KINERJA GURU SMP NEGERI SEKECAMATAN SUNGAI APIT KABUPATEN SIAK
}

\author{
Afrizal 1) \\ Suarman ${ }^{2)}$ \\ Daviq Chairilsyah ${ }^{3)}$ \\ 1) Post Graduate Student of Riau University \\ 2) Lecturer of Education Management Study Programme PPs University of Riau \\ 3) Lecturer of Education Management Study Programme PPs University of Riau
}

ABSTRACT

This study aims to determine the contribution of variables (1) pedagogical competence on teacher performance, (2) achievement motivation on teacher performance, (3) pedagogical competence and achievement motivation together on teacher performance. The research respondents were 85 state junior high school teachers in Sungai Apit subdistrict obtained by proportional random sampling technique. Data collection was carried out through questionnaires as research instruments. Analysis of the data used is descriptive analysis, inferential statistical analysis and hypothesis testing. The instrument reliability coefficient was calculated using the Cronbach alpha formula. Partially the results of the study indicate that there is a significant contribution between pedagogical competence on teacher performance of 0.908, and there is a significant contribution between achievement motivation on teacher performance of 0.953. While simultaneously there is a contribution of pedagogic competence and achievement motivation to teacher performance by 0.956 .

Keywords: Pedagogical Competence; Achievement motivation; Teacher Performance

\begin{abstract}
ABSTRAK
Penelitian ini bertujuan untuk mengetahui adanya kontribusi variabel (1) kompetensi pedagogik terhadap kinerja guru, (2) motivasi berprestasi terhadap kinerja guru, (3) kompetensi pedagogik dan motivasi berprestasi secara bersama-sama terhadap kinerja guru. Responden penelitian adalah guru SMP Negeri se-Kecamatan Sungai Apit yang berjumlah 85 orang diperoleh dengan teknik proportional random sampling. Pengumpulan data dilakukan melalui penyebaran angket sebagai instrumen penelitian. Analisis data yang digunakan yaitu analisis deskriptif, analisis statistik inferensial dan pengujian hipotesis. Koefisien reliabilitas instrumen dihitung menggunakan rumus alpha cronbach. Secara parsial hasil penelitian menunjukkan adanya kontribusi yang signifikan antara kompetensi pedagogik terhadap kinerja guru sebesar 0,908, dan terdapat kontribusi secara signifikan antara motivasi berprestasi terhadap kinerja guru sebesar 0,953. Sedangkan secara simultan terdapat kontribusi kompetensi pedagogik dan motivasi berprestasi terhadap kinerja guru sebesar 0,956 .
\end{abstract}

Kata Kunci : Kompetensi Pedagogik; Motivasi Berprestasi; Kinerja Guru 


\section{PENDAHULUAN}

Guru pada prinsipnya memiliki potensi yang cukup tinggi untuk berkreasi guna meningkatkan kinerjanya. Namun potensi yang dimiliki guru berkreasi sebagai upaya meningkatkan kinerjanya tidak selalu berkembang secara wajar dan lancar disebabkan adanya pengaruh dari berbagai faktor baik yang muncul dalam diri pribadi guru itu sendiri maupun yang terdapat di luar pribadi guru. Tidak dapat dipungkiri bahwa kondisi di lapangan mencerminkan keadaan guru yang tidak sesuai dengan harapan seperti lemahnya kompetensi pedagogik yang dimiliki seorang guru dan motivasi berprestasi guru yang rendah. Kenyataan ini sangat memprihatinkan dan mengundang berbagai pertanyaan tentang konsistensi guru terhadap profesinya.

Disisi lain kinerja guru pun dipersoalkan ketika memperbincangkan masalah peningkatan mutu pendidikan. Untuk itu faktor-faktor yang mempengaruhi kinerja guru dipandang perlu untuk dipelajari, ditelaah dan dikaji secara mendalam agar dapat memberikan gambaran yang jelas faktor yang lebih berperan dan urgen yang mempengaruhi kinerja guru.

Kinerja guru menjadi salah satu hal pendukung dari tinggi rendahnya mutu pendidikan. Akan tetapi kinerja guru ini dipengaruhi oleh berbagai macam faktor. Menurut Susanto (2012:198) menyebutkan bahwa kinerja guru ini dipengaruhi oleh faktor : (a) Motivasi, (b) kompetensi guru dan (c) kepemimpinan kepala sekolah.

Sepuluh kompetensi guru tersebut juga merupakan bagian dari kompetensi pedagogik yang harus dimiliki oleh setiap guru. Berdasarkan peraturan pemerintah (PP) Nomor 2007 tentang Guru, dinyatakan bahwasanya kompetensi yang harus dimiliki oleh
Guru meliputi kompetensi profesional yang diperoleh melalui pendidikan profesi.

Dengan memiliki kemampuan dan kompetensi yang kompleks tersebut diharapkan memberikan kontribusi yang nyata dan mendukung terhadap kinerja guru disekolah. Dengan kemampuan dan kompetensi yang telah dikuasai guru diharapkan juga menunjang proses pendidikan dan tentunya diharapkan mampu memberikan sumbangsi yang nyata terhadap dunia pendidikan nasional.

Salah satu faktor yang mampu mempengaruhi kinerja guru ialah motivasi berprestasi yang dimiliki guru tersebut. Bagaimana mungkin seorang guru mampu memiliki kinerja tinggi dalam mengajar jika tidak memiliki motivasi yang tinggi dalam bekerja. Motivasi merupakan faktor utama yang harus dimiliki dalam diri seseorang, dengan motivasi yang tinggi akan mempengaruhi semangat seseorang untuk lebih giat dalam bekerja. Motivasi akan lahir dari rangkaian target yang direncanakan oleh seseorang. Guru diharapkan memiliki motivasi yang tinggi dengan berbagai rancangan target yang dimilikinya.

Mulyasa (2009:10) menyatakan bahwa salah satu faktor yang menyebabkan rendahnya profesionalisme guru adalah kurangnya motivasi guru dalam meningkatkan kualitas diri. Dalam diri seorang guru yang diharapkan adalah perlunya mempunyai motivasi untuk mengaktualisasikan dirinya sebagai pendidik yang dapat dijadikan panutan bagi peserta didiknya. Jadi motivasi untuk berprestasi dari guru sangat diperlukan dalam meningkatkan kualitas pendidikan.

Berdasarkan hasil observasi dan data yang peneliti dapatkan pada tanggal 12 Juli 2017, menunjukkan nilai 
atau persentase kinerja guru yang terbilang rendah sebab dari 9 standar kompetensi guru yang ditetapkan oleh UPTD Pendidikan Kecamatan Sungai Apit, pada poin 3 (guru diharapkan mampu mengembangkan kurikulum dengan baik) total dari 108 jumlah guru SMP Negeri yang ada di Kecamatan Sungai Apit 20,3\% diantaranya tidak mampu mengembangkan kurikulum dengan baik, pada poin 6 (mampu berkomunikasi secara efektif) total dari 108 jumlah guru SMP Negeri yang ada di Kecamatan Sungai Apit 27,2\% diantaranya tidak mampu berkomunikasi secara efektif dan pada poin 7 (menguasai dan memanfaatkan teknologi informasi) total dari 108 jumlah guru SMP Negeri yang ada di Kecamatan Sungai Apit 30,12\% diantaranya tidak mampu menguasai dan memanfaatkan teknologi informasi.

Selain itu masalah yang peneliti temukan dilapangan tentang rendahnya kinerja guru atau indikasi penyimpangan yang dilakukan oleh guru, diantaranya :

1. Dilihat dari absensi guru, $22,5 \%$ guru datang terlambat sehingga dalam proses kegiatan belajar mengajar tidak efektif. Datang dan pulang tidak sesuai dengan jadwal yang sekolah tentukan.

2. Dilihat dari disiplin tugas, ada $34,8 \%$ guru yang tidak tepat waktu dalam pengumpulan RPP.

3. Ada $28,6 \%$ guru yang tidak termotivasi mengikuti kegiatan MGMP yang diadakan sekolah.

Berdasarkan latar belakang masalah yang telah diuraikan di atas, maka masalah penelitian dirumuskan sebagai berikut :
1. Seberapa besar kontribusi kompetensi pedagogik terhadap kinerja guru SMP Negeri seKecamatan Sungai Apit Kabupaten Siak?

2. Seberapa besar kontribusi motivasi berprestasi terhadap kinerja guru SMP Negeri se-Kecamatan Sungai Apit Kabupaten Siak?

3. Seberapa besar kontribusi kompetensi pedagogik dan motivasi berprestasi terhadap kinerja guru SMP Negeri se-Kecamatan Sungai Apit Kabupaten Siak?

\section{METODOLOGI PENELITIAN}

Penelitian ini menguji tiga variabel yang akan diteliti dan untuk mengetahui ada tidaknya kontribusi antara variabel independen dengan variabel dependen. Sehubungan dengan ini maka yang menjadi variabel $\mathrm{X}_{1}$ (independen) adalah kompetensi pedagogik, variabel $\mathrm{X}_{2}$ (independen) adalah motivasi berprestasi dan variabel $\mathrm{Y}$ (dependen) adalah kinerja guru.

Populasi dalam penelitian ini adalah guru SMP Negeri se-Kecamatan Sungai Apit yang berjumlah 85 orang. Penentuan jumlah sampel dilakukan menggunakan rumus Taro Yamane. Sampel dalam penelitian ini adalah 85 guru dari 108 guru. Teknik yang digunakan dalam pengambilan sampel adalah dengan cara proporsional random sampling.

Teknik pengumpulan data yang digunakan dalam penelitian ini adalah angket dan tes. Angket merupakan teknik pengumpulan data yang dilakukan dengan cara memberi seperangkat pertanyaan atau pernyataan tertulis kepada responden untuk dijawab. Angket dalam penelitian ini terdiri dari butir pernyataan yang terkait dengan motivasi berprestasi dan kinerja guru dan untuk variable kompetensi pedagogik menggunakan tes. Teknik 
yang digunakan dalam analisis data adalah analisis statistik deskriptif dan analisis statistik inferensial.

\section{HASIL PENELITIAN DAN}

\section{PEMBAHASAN}

\subsubsection{Deskripsi Data Kinerja Guru} (Y)

Berdasarkan hasil perhitungan terhadap data kinerja guru diperoleh skor empiris terendah yang dicapai responden adalah 67 dan skor tertinggi adalah 110 dengan rentang sebesar 43 . Perhitungan terhadap distribusi skor tersebut adalah: (1) skor rata-rata = 88,37 ; (2) simpangan baku = 1,299; (3) median $=87$; dan (4) modus $=70$. Untuk lebih jelasnya, deskripsi data penelitian tentang kinerja guru dapat dilihat pada tabel 4.1 :

\section{Tabel 4.1 Perhitungan Statistik Data Kinerja Guru (Y)}

\section{Statistics}

Kinerja_Guru_Y

\begin{tabular}{|c|c|c|}
\hline $\mathrm{N}$ & $\begin{array}{l}\text { Valid } \\
\text { Missing }\end{array}$ & $\begin{array}{r}85 \\
0\end{array}$ \\
\hline \multicolumn{2}{|c|}{ Mean } & 88.37 \\
\hline \multicolumn{2}{|c|}{ Median } & 87 \\
\hline \multicolumn{2}{|c|}{ Mode } & 70 \\
\hline \multicolumn{2}{|c|}{ Std. Deviation } & 1.299 \\
\hline \multicolumn{2}{|c|}{ Variance } & 168.88 \\
\hline \multicolumn{2}{|c|}{ Range } & 43 \\
\hline \multicolumn{2}{|c|}{ Minimum } & 67 \\
\hline \multicolumn{2}{|c|}{ Maximum } & 110 \\
\hline \multicolumn{2}{|c|}{ Sum } & 7512 \\
\hline
\end{tabular}

Sebaran skor kinerja guru SMP Negeri se-Kecamatan Sungai Apit Kabupaten Siak disajikan dalam daftar distribusi frekuensi dengan lima kategori yaitu sangat tinggi, tinggi, sedang, rendah, dan sangat rendah.
Selanjutnya penyebaran distribusi frekuensi data kinerja guru SMP Negeri se-Kecamatan Sungai Apit Kabupaten Siak dapat dilihat pada tabel 4.2 berikut ini :

Tabel 4.2 Distribusi Frekuensi Skor Kinerja Guru (Y)

\begin{tabular}{|c|c|c|c|}
\hline \multirow[b]{2}{*}{ Kategori } & \multirow[b]{2}{*}{ Kelas Interval } & \multicolumn{2}{|c|}{ Frekuensi } \\
\hline & & Absolut & Relatif (\%) \\
\hline Sangat Tinggi & $103-110$ & 17 & $20 \%$ \\
\hline Tinggi & $94-102$ & 15 & $17,65 \%$ \\
\hline Sedang & $85-93$ & 19 & $22,35 \%$ \\
\hline Rendah & $76-84$ & 16 & $18,82 \%$ \\
\hline Sangat Rendah & $67-75$ & 18 & $21,18 \%$ \\
\hline $\mathbf{J u}$ & & 85 & 100 \\
\hline
\end{tabular}

Berdasarkan tabel 4.2 diketahui distribusi frekuensi skor kinerja guru terdiri dari lima kelas interval. Skor tertinggi kinerja guru terdapat pada 
interval 85-93 sebanyak 19 orang atau $22,35 \%$. Dengan demikian skor kinerja guru SMP Negeri se-Kecamatan Sungai Apit Kabupaten Siak berada dalam kategori sedang.

\subsubsection{Deskripsi Data Kompetensi Pedagogik (X1)}

Berdasarkan hasil perhitungan terhadap data kompetensi pedagogik diperoleh skor empiris terendah yang dicapai responden adalah 9 dan skor tertinggi adalah 25 dengan rentang sebesar 16. Perhitungan terhadap distribusi skor tersebut adalah: (1) skor rata-rata $=17,14 ;(2)$ simpangan baku $=$ 4,015; (3) median = 17; dan (4) modus $=18$. Untuk lebih jelasnya, deskripsi data penelitian tentang kompetensi pedagogik dapat dilihat pada tabel 4.3 :

Tabel 4.3 Perhitungan Statistik Data Kompetensi Pedagogik (X1)

Statistics

Kompetensi_Pedagogik_X

\begin{tabular}{|l|r|}
\hline N & Valid \\
Mean & Missing \\
Median & 05 \\
Mode & \\
Std. Deviation & 17.14 \\
Variance & 17 \\
Range & 18 \\
Minimum & 4.015 \\
Maximum & 16.12 \\
Sum & 16 \\
\hline
\end{tabular}

Sebaran skor kompetensi pedagogik guru SMP Negeri seKecamatan Sungai Apit Kabupaten Siak disajikan dalam daftar distribusi frekuensi dengan lima kategori yaitu sangat tinggi, tinggi, sedang, rendah, dan sangat rendah. Selanjutnya penyebaran distribusi frekuensi data kompetensi pedagogik guru SMP Negeri se-Kecamatan Sungai Apit Kabupaten Siak dapat dilihat pada tabel 4.4 berikut ini :

Tabel 4.4 Distribusi Frekuensi Skor Kompetensi Pedagogik (X1)

\begin{tabular}{|c|c|c|c|}
\hline \multirow{2}{*}{ Kategori } & \multirow{2}{*}{ Kelas Interval } & \multicolumn{2}{|c|}{ Frekuensi } \\
\cline { 3 - 4 } & $23-25$ & 9 & Relatif (\%) \\
\hline Sangat Tinggi & $19-22$ & 24 & 10,59 \\
\hline Tinggi & $15-18$ & 28 & 32,23 \\
\hline Sedang & $12-14$ & 18 & 21,18 \\
\hline Rendah & $9-11$ & 6 & 7,06 \\
\hline Sangat Rendah & & 85 & 100 \\
\hline \multicolumn{2}{|c|}{ Jumlah }
\end{tabular}


Berdasarkan tabel 4.4 diketahui distribusi frekuensi skor kompetensi pedagogik terdiri dari lima kelas interval. Skor tertinggi kompetensi pedagogik terdapat pada interval 15-18 sebanyak 28 orang atau 32,94 \%. Dengan demikian skor kompetensi pedagogik guru SMP Negeri seKecamatan Sungai Apit Kabupaten Siak berada dalam kategori sedang. Penyebaran distribusi frekuensi dari kompetensi pedagogik dapat ditunjukan pada gambar berikut :

\subsubsection{Deskripsi Data Motivasi Berprestasi (X2) \\ Berdasarkan hasil perhitungan} terhadap data motivasi berprestasi diperoleh skor empiris terendah yang dicapai responden adalah 68 dan skor tertinggi adalah 112 dengan rentang sebesar 44. Perhitungan terhadap distribusi skor tersebut adalah: (1) skor rata-rata $=89,91 ;(2)$ simpangan baku $=$ 1,$390 ;(3)$ median $=90$; (4) modus $=$ 70. Untuk lebih jelasnya, deskripsi data penelitian tentang motivasi berprestasi dapat dilihat pada tabel 4.5 :

\section{Tabel 4.5 Perhitungan Statistik Data Motivasi Berprestasi (X2) Statistics}

Motivasi_Berprestasi_X

\begin{tabular}{|lr|r|}
\hline N & Valid & 85 \\
Mean & Missing & 0 \\
Median & 89.91 \\
Mode & & 90 \\
Std. Deviation & & 70 \\
Variance & 1.390 \\
Range & 193.26 \\
Minimum & 44 \\
Maximum & 68 \\
Sum & & 112 \\
\hline
\end{tabular}

Sebaran skor motivasi berprestasi guru SMP Negeri seKecamatan Sungai Apit disajikan dalam daftar distribusi frekuensi dengan lima kategori yaitu sangat tinggi, tinggi, sedang, rendah, dan sangat rendah. Selanjutnya penyebaran distribusi frekuensi data motivasi berprestasi guru SMPN Kecamatan Sungai Apit dapat dilihat pada tabel 4.6 berikut ini;

Tabel 4.6 Distribusi Frekuensi Skor Motivasi Berprestasi (X2)

\begin{tabular}{|c|c|c|c|}
\hline \multirow[b]{2}{*}{ Kategori } & \multirow[b]{2}{*}{ Kelas Interval } & \multicolumn{2}{|c|}{ Frekuensi } \\
\hline & & Absolut & Relatif (\%) \\
\hline Sangat Tinggi & $104-112$ & 19 & 22,35 \\
\hline Tinggi & $95-103$ & 15 & 17,65 \\
\hline Sedang & $86-94$ & 21 & 24,71 \\
\hline Rendah & $77-85$ & 13 & 15,29 \\
\hline Sangat Rendah & $68-76$ & 19 & 22,35 \\
\hline \multicolumn{2}{|c|}{ Jumlah } & 85 & 100 \\
\hline
\end{tabular}


Berdasarkan tabel 4.6 diketahui distribusi frekuensi skor motivasi berprestasi terdiri dari lima kelas interval. Skor tertinggi motivasi berprestasi terdapat pada interval 86-94 sebanyak 21 orang atau $24,71 \%$. Dengan demikian skor motivasi berprestasi guru SMP Negeri seKecamatan Sungai Apit Kabupaten Siak berada dalam kategori sedang.

\subsection{Pengujian Persyaratan Analisis}

Analisis data untuk menguji hipotesis penelitian dilakukan dengan menggunakan analisis statistik parametik.Sebelum melakukan uji statistika parametrik terlebih dahulu peneliti melalukan uji persyaratan analisis yaitu uji normalitas. Uji normalitas dilakukan untuk mengetahui normal tidaknya sebaran data yang akan di analisis. Data tersebut meliputi variabel kinerja guru (Y), kompetensi pedagogic $\left(\mathrm{X}_{1}\right)$ dan motivasi berpretasi $\left(\mathrm{X}_{2}\right)$. Uji normalitas menggunakan SPSS versi 20.

\subsubsection{Uji Normalitas}

Uji normalitas data pada penelitian ini menggunakan uji Kolmogorov-smirnov, dengan taraf signifikan yang digunakan sebagai aturan untuk menerima atau menolak pengujian normalitas atau ada tidaknya suatu distribusi data $\alpha=0,05$. Untuk menerima atau menolak hipotesis dengan cara membandingkan nilai signifikan variabel dengan $\alpha=0,05$. Adapun kaidah keputusan, data dinyatakan berdistribusi normal jika nilai signifikan $>\alpha=0,05$. Hasil pengujian normalitas dari ketiga variabel dapat dilihat pada tabel dibawah ini :

Tabel 4.7 Pengujian Normalitas Pengujian Normalitas Kompetensi Pedagogik, Motivasi Berprestasi terhadap Kinerja Guru Tests of Normality

\begin{tabular}{|l|r|r|r|}
\hline & \multicolumn{3}{|c|}{ Kolmogorov-Smirnov $^{\mathrm{a}}$} \\
\cline { 2 - 4 } & Statistic & Df & \multicolumn{1}{c|}{ Sig. } \\
\hline Kompetensi_Pedagogik_X1 & .084 & 85 & $.200^{*}$ \\
Motivasi_Berprestasi_X2 & .093 & 85 & .065 \\
Kinerja_Guru_Y & .094 & 85 & .063 \\
\hline
\end{tabular}

Kenormalan data dalam penelitian ini dapat diketahui dari uji normalitas Kolmogorov-Smirnov dari masing-masing variabel. Untuk melakukan pengujian normalitas data penelitian diperlukan hipotesis sebagai berikut :

$\mathrm{H}_{0} \quad$ : data berdistribusi normal $\mathrm{H}_{\mathrm{a}} \quad$ : data tidak berdistribusi normal Terlihat dari tabel 4.7 pada kolom sig, diperoleh hasil signifikansi variabel kinerja guru (Y) berdistribusi normal, karena nilai sig lebih besar dari nilai alpa $(0,063>0,05)$, variabel kompetensi pedagogik $\left(\mathrm{X}_{1}\right)$ berdistribusi normal karena sig lebih besar dari nilai alpha $(0,200>0,05)$, dan variabel motivasi berprestasi $\left(\mathrm{X}_{2}\right)$ juga berdistribusi normal, karena nilai sig lebih besar dari nilai alpa $(0,065>$ $0,05)$. Nilai signifikansi masing-masing variabel ini > 0,05 yang berarti bahwa $\mathrm{H}_{0}$ diterima atau data dari masingmasing variabel berdistribusi normal. Dengan demikian, persyaratan analisis regresi terpenuhi. 


\subsection{Pengujian}

Penelitian

Dari hasil pengujian persyaratan analisis menunjukan bahwa skor setiap variabel penelitian telah memenuhi syarat untuk dipakai dalam pengujian statistik lebih lanjut yaitu pengujian hipotesis. Pengujian hipotesis dalam penelitian bertujuan untuk menguji tiga hipotesis yang telah dirumuskan di bab sebelumnya. Berikut ini disajikan pengujian hipotesis penelitian.

\subsubsection{Kontribusi Kompetensi}

Pedagogik terhadap Kinerja

Guru
Hipotesis yang akan di uji adalah

$$
\begin{array}{ll}
\mathrm{H}_{\mathrm{o}} & : \rho_{\mathrm{y} 1} \leq 0 \\
\mathrm{H}_{1} & : \rho_{\mathrm{y} 1}>0
\end{array}
$$

Di sini uji hipotesis 0 (Ho) yang menyatakan tidak terdapat hubungan antara kompetensi pedagogik dengan kinerja guru, melawan hipotesis (Hi) yang menyatakan terdapat hubungan antara kompetensi pedagogic dengan kinerja guru. Pengujian hipotesis tersebut dilakukan dengan menggunakan teknis analisis regresi.

Tabel 4.8 Analysis of Variance (ANOVA) Hubungan Kompetensi Pedagogik $\left(\mathrm{X}_{1}\right)$

\begin{tabular}{|c|c|c|c|c|}
\hline Sumber variasi & Jumlah Kuadrat & Df & $F_{\text {hitung }}$ & $F_{\text {tabel }}(0,05)$ \\
\hline Regresi & 12879,664 & 1 & \multirow{3}{*}{818,358} & \multirow{3}{*}{3,10} \\
\hline Residual & 1306,289 & 83 & & \\
\hline Total & 14185,953 & 84 & & \\
\hline
\end{tabular}
dengan Kinerja Guru (Y)

Tabel 4.8 menunjukan Fhitung sebesar 818,358 membandingkan dengan $\mathrm{F}_{\text {tabel }}$ df1 untuk taraf signifikansi $5 \%$ yaitu 3,10 . Maka $\mathrm{F}$ hitung $(818,358)>$
$\mathrm{F}_{\text {tabel }}(3,10)$ artinya terdapat hubungan yang linier antara kompetensi pedagogik dengan kinerja guru.

Tabel 4.9 Uji Korelasi Person antara Variabel Kompetensi Pedagogik $\left(\mathrm{X}_{1}\right)$ dan Kinerja Guru (Y)

\begin{tabular}{|cccc|}
\hline Variabel & $\mathbf{N}$ & Korelasi person & Sig (2-tailed) \\
\hline $\mathrm{X}_{1} \mathrm{Y}$ & 85 & 0,953 & 0.000 \\
\hline
\end{tabular}

Dari tabel 4.9 diperoleh korelasi person sebesar 0,953 hal ini menunjukkan bahwa kompetensi pedagogik dengan kinerja guru. Hubungan korelasi antara kompetensi pedagogik dengan kinerja guru adalah Tabel 4.10 Uji t Hitung Variabel Kompetensi Pedagogik $\left(\mathrm{X}_{1}\right)$ dengan Kinerja Guru (Y)

\begin{tabular}{|c|c|c|c|}
\hline Model & B & thitung & t tabel \\
\hline (Konstan) & 35,516 & 18,719 & \multirow{2}{*}{1,662} \\
\cline { 1 - 2 } Kompetensi Pedagogik $\left(\mathrm{X}_{1}\right)$ & 3,084 & 28,607 & \\
\hline
\end{tabular}


Berdasarkan tabel 4.10 diperoleh nilai $\mathrm{a}=35,516$ dan $\mathrm{b}=3,084$ sehingga persamaan regresinya menjadi $\mathrm{Y}=$ $35,516+3,084$ sehingga persamaan tersebut dapat diartikan bahwa hubungan kedua variabel tersebut adalah signifikan linier, artinya setiap kenaikan 1 satuan kompetensi pedagogik $\left(\mathrm{X}_{1}\right)$ akan diikuti peningkatan kinerja guru sebesar 3,084.

Dari tabel coefficient diperoleh nilai uji $\mathrm{t}$ ( $\mathrm{t}_{\text {hitung }}$ ) sebesar 18,719 sedangkan nilai $t_{\text {tabel }} 1,662$ atau bisa dikatakan nilai $t_{\text {hitung }}>t_{\text {tabel }}$, ini berarti $\mathrm{H}_{0}$ ditolak dan $\mathrm{H}_{\mathrm{a}}$ diterima sehingga terdapat hubungan yang signifikan antara variabel kompetensi pedagogik $\left(\mathrm{X}_{1}\right)$ dengan kinerja guru $(\mathrm{Y})$.

\subsubsection{Kontribusi Motivasi Berprestasi terhadap Kinerja Guru}

Hipotesis yang akan diuji adalah

$$
\begin{array}{ll}
\mathrm{H}_{\mathrm{o}} & : \rho_{\mathrm{y} 2} \leq 0 \\
\mathrm{H}_{1} & : \rho_{\mathrm{y} 2}>0
\end{array}
$$

Di sini uji hipotesis $0\left(\mathrm{H}_{0}\right)$ yang menyatakan tidak terdapat hubungan antara motivasi berprestasi dengan kinerja guru, melawan hipotesis $\left(\mathrm{H}_{\mathrm{a}}\right)$ yang menyatakan terdapat hubungan antara motivasi berpretasi dengan kinerja guru. Pengujian hipotesis tersebut dilakukan dengan menggunakan teknis analisis regresi.

Tabel 4.11 Analysis of Variance (ANOVA) Motivasi Berprestasi ( $\mathrm{X}_{2}$ ) dengan

\begin{tabular}{|c|c|c|c|c|}
\hline Sumber variasi & Jumlah Kuadrat & Df & F hitung & $F_{\text {tabel }}(\mathbf{0 , 0 5})$ \\
\hline Regresi & 135,226 & 1 & \multirow{3}{*}{169,233} & \multirow{3}{*}{3,10} \\
\hline Residual & 663,287 & 83 & & \\
\hline Total & 141,859 & 84 & & \\
\hline
\end{tabular}
Kinerja Guru (Y)

Berdasarkan tabel 4.11 menunjukan $F_{\text {hitung }}$ sebesar 169,233 membandingkan dengan $\mathrm{F}_{\text {tabel }}$ df1 untuk taraf signifikansi 5\% yaitu 3,10. Maka $\mathrm{F}$ hitung $(169,233)>F_{\text {tabel }}(3,10)$ artinya terdapat hubungan yang linier antara motivasi berprestasi dan kinerja guru.

Tabel 4.12 Uji Korelasi Person antara variabel Motivasi Berprestasi $\left(\mathrm{X}_{2}\right)$ dan Kinerja Guru (Y)

\begin{tabular}{|c|c|c|c|}
\hline Variabel & $\mathbf{N}$ & Korelasi person & Sig (2-tailed) \\
\hline $\mathrm{X}_{2} \mathrm{Y}$ & 85 & 0,976 & 0.000 \\
\hline
\end{tabular}

Dari tabel 4.12 diperoleh korelasi person sebesar 0,976 hal ini menunjukan bahwa terdapat hubungan yang signifikan antara motivasi berprestasi dengan kinerja guru. Hubungan korelasi antara motivasi berprestasi dengan kinerja guru adalah sangat kuat, Dengan Pvalue/Sig sama dengan $0,00<0,05$. dapat disimpulkan terdapat hubungan yang signifikan antara kedua variabel.

Tabel 4.13 Uji t Hitung Variabel Motivasi Berprestasi $\left(\mathrm{X}_{2}\right)$ dengan Kinerja Guru

(Y) 


\begin{tabular}{|c|c|c|c|}
\hline Model & B & thitung & t$_{\text {tabel }}$ \\
\hline (Konstan) & 6,312 & 3,127 & \multirow{2}{*}{1,662} \\
\hline Motivasi Berprestasi $\left(\mathrm{X}_{2}\right)$ & 0,913 & 41,136 & \\
\hline
\end{tabular}

Dari tabel 4.13 diperoleh nilai a $=6,312$ dan $\mathrm{b}=0,913$ sehingga persamaan regresinya menjadi $\mathrm{Y}=$ $6,312+0,913 \mathrm{X}_{2}$. Ini berarti setiap kenaikan 1 satuan motivasi berprestasi $\left(\mathrm{X}_{2}\right)$ akan diikuti peningkatan kinerja guru (Y) sebesar 0,913.

Dari tabel diatas dapat diperoleh nilai uji $\mathrm{t}$ ( $\mathrm{t}_{\text {hitung }}$ ) sebesar 3,127 sedangkan nilai t tabel sebesar 1,662 atau bisa dikatakan nilai $t_{\text {hitung }}>t_{\text {tabel }}$, ini berarti $\mathrm{H}_{0}$ ditolak dan $\mathrm{H}_{\mathrm{a}}$ diterima sehingga terdapat hubungan yang signifikan antara variabel motivasi berprestasi dengan kinerja guru.

\subsubsection{Kontribusi Kompetensi Pedagogik dan Motivasi}

Tabel 4.14 Analysis of Variance (ANOVA) Kompetensi Pedagogik (X1) dan Motivasi Berprestasi (X2) dengan Kinerja Guru

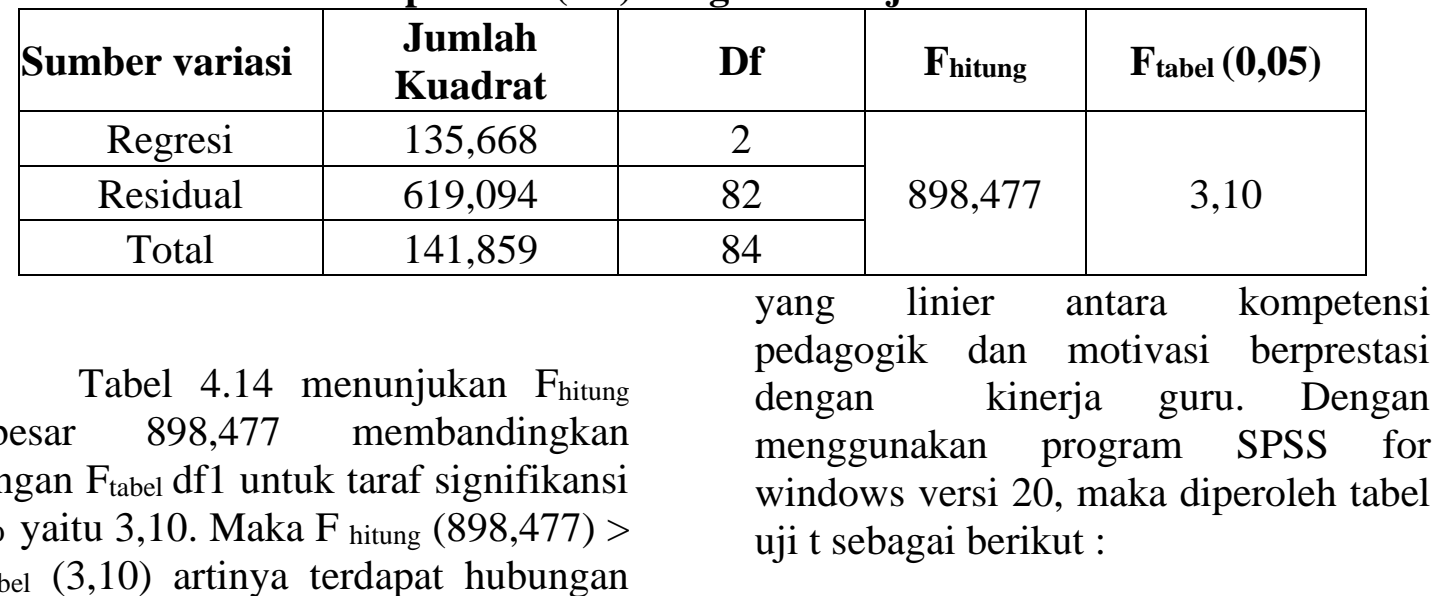

Tabel 4.15 Uji t Hitung Kompetensi Pedagogik dan Motivasi Berprestasi dengan Kinerja Guru

\begin{tabular}{|c|c|c|c|}
\hline Model & B & thitung & \multirow{2}{*}{ tabel } \\
\hline (Konstan) & 11,331 & 3,968 & \multirow{2}{*}{1,662} \\
\cline { 1 - 3 } Kompetensi Pedagogik X1 & 0,644 & 2,419 & \\
\hline Motivasi Berprestasi X2 & 0,734 & 9,540 & \\
\hline
\end{tabular}


Dari tabel 4.15 diperoleh nilai a $=11,331, b_{1}=0,644, \quad b_{1}=0,734$ sehingga persamaan regresinya menjadi $\mathrm{Y}=11,331+0,644 \mathrm{X}_{1}+0,734 \mathrm{X}_{2}$. Ini berarti setiap kenaikan 1 satuan kompetensi pedagogik $\left(\mathrm{X}_{1}\right)$ dan motivasi berprestasi $\left(\mathrm{X}_{2}\right)$ akan diikuti peningkatan kinerja guru (Y) sebesar 11,331. Kemudian pada nilai uji $t$ ( $t_{\text {hitung }}$ ) sebesar 3,968, sedangkan nilai $\mathrm{t}$ tabel sebesar 1,662 atau bisa dikatakan nilai $t_{\text {hitung }}>\mathrm{t}_{\text {tabel}}$, ini berarti $\mathrm{H}_{0}$ ditolak dan $\mathrm{H}_{\mathrm{a}}$ diterima sehingga terdapat hubungan yang signifikan antara variabel kompetensi pedagogik dan motivasi berprestasi dengan kinerja guru.

\subsubsection{Kontribusi Antar Variabel}

Untuk mengetahui berapa kontribusi yang disumbangkan oleh masing-masing variabel silahkan baca tabel berikut ini :

Tabel 4.16 Kontribusi Masing-masing Variabel Terhadap Variabel Y

\begin{tabular}{|l|c|c|c|c|}
\hline \multicolumn{1}{|c|}{ Variabel } & R & R Square & Df & Sig.F. Change \\
\hline $\begin{array}{l}\text { Kompetensi pedagogik dengan } \\
\text { kinerja guru }\end{array}$ & 0,953 & 0,908 & 1 & 0,000 \\
\hline $\begin{array}{l}\text { Motivasi berprestasi dengan } \\
\text { kinerja guru }\end{array}$ & 0,976 & 0,953 & 1 & 0,000 \\
\hline $\begin{array}{l}\text { Kompetensi pedagogik dan } \\
\text { motivasi berprestasi dengan } \\
\text { kinerja guru }\end{array}$ & 0,978 & 0,956 & 2 & 0,000 \\
\hline
\end{tabular}

Sumber olahan data SPSS versi 20

Pada tabel 4.16 diketahui korelasi antara kompetensi pedagogik dengan kinerja guru adalah 0,953 . Koefesien Determinasi $\left(\mathrm{r}^{2}\right)=0,908$ atau $90,8 \%$ artinya besarnya kontribusi kompetensi pedagogik dengan kinerja guru adalah 90,8\%, sedangkan sisanya dipengaruhi oleh faktor lain. Selanjutnya diketahui korelasi antara motivasi berprestasi dengan kinerja guru adalah 0,976. Koefesien Determinasi $\left(r^{2}\right)=0,953$ atau 95,3\% artinya besarnya kontribusi motivasi berprestasi dengan kinerja guru adalah 95,3\% sedangkan sisanya dipengaruhi oleh faktor lain. Setelah itu korelasi antara kompetensi pedagogik dan motivasi berprestasi dengan kinerja guru adalah 0,978. Koefesien Determinasi $\left(r^{2}\right)=0,956$ atau 95,6\% artinya besarnya kompetensi pedagogik dan motivasi berprestasi dengan kinerja guru adalah 95,6 \%, sedangkan sisanya dipengaruhi faktor lain.

\section{SIMPULAN}

Dari hasil penelitian ini maka diperoleh simpulan yang dirumuskan sebagai berikut:

1. Terdapat kontribusi yang signifikan kompetensi pegadogik terhadap kinerja guru SMP Negeri se-Kecamatan Sungai Apit Kabupaten Siak. Artinya semakin baik kompetensi pedagogic guru-guru di SMP Negeri seKecamatan Sungai Apit Kabupaten Siak, maka akan semakin baik pula derajat kinerja guru.

2. Terdapat kontribusi yang signifikan motivasi berprestasi terhadap kinerja guru SMP Negeri seKecamatan Sungai Apit Kabupaten Siak. Artinya semakin baik motivasi berprestasi di SMP Negeri seKecamatan Sungai Apit 
Kabupaten Siak, maka semakin tinggi pula derajat kinerja guru.

3. Terdapat kontribusi secara simultan kompetensi pedagogik dan motivasi berprestasi terhadap kinerja guru SMP Negeri seKecamatan Sungai Apit Kabupaten Siak. Dengan demikian dapat dikatakan bahwa kompetensi pedagogik yang efektif dan semakin baiknya motivasi berprestasi guru, maka akan semakin meningkatkan derajat kinerja guru di SMP Negeri seKecamatan Sungai Apit Kabupaten Siak.

\section{SARAN}

Berdasarkan temuan penelitian, maka saran yang akan diberikan adalah:

1. Dari dua variabel bebas yang diteliti dalam penelitian ini menunjukkan bahwa motivasi berprestasi memberikan pengaruh yang lebih dominan jika dibandingkan dengan kompetensi pedagogik. Untuk itu, para guru diharapkan mampu meningkatkan motivasi berprestasi mereka sehingga kinerja guru pun dapat ditingkatkan.

2. Guru hendaknya bisa memotivasi diri untuk lebih berprestasi dalam menjalankan tugasnya agar lebih baik lagi secara berkelanjutan.

3. Kepala sekolah sebagai atasan dan manager hendaknya memperhatikan guru-guru yang berprestasi dan mempromosikan mereka dan juga memberikan reward atau bonus kepada mereka sehingga bisa memotivasi terhadap guru-guru yang lainya.
4. Kepala sekolah melakukan terobosan dengan mengadakan seleksi guru berprestasi, memberikan kesempatan kepada guru untuk mendapat kepercayaan berimprovisasi, dan memberikan kejelasan tentang jenjang karir sebagaimana diamanatkan dalam UU no.14 tahun 2005 tentang guru dan dosen, bahwa guru yang diangkat oleh pemerintah atau pemerintah daerah dapat ditempatkan pada jabatan struktural.

5. Kepada para peneliti untuk melakukan penelitian lanjutan dengan mengkaji faktor-faktor lain yang mempengaruhi kinerja guru sehingga wawasan menjadi lebih luas.

\section{DAFTAR PUSTAKA}

Anwar Prabu Mangkunegara. (2003). Perencanaan dan Pengembangan Sumber Daya Manusia. Bandung: Refika Aditama

Danim. Sudarwan, (2008). Kinerja Staff dan Organisasi. Bandung: CV Pustaka Setia

Dharma, Agus. (2003). Manajemen Supervisi: Petunjuk Praktis Bagi Para Supervisor. Jakarta: Raja Grafindo Persada

Hamalik, Oemar. (2004). Proses Belajar Mengajar. Jakarta : Bumi Aksara

Hasibuan, Malayu, S.P., (2005). Manajemen Sumber Daya Manusia. Edisi Revisi. Jakarta : Bumi Aksara 
Muhibbin Syah. (2003). Psikologi Pendidikan dengan Pendekatan Baru. Bandung: Remaja Rosdakarya

Sugiyono, (2014). Metode Penelitian Administrasi. Bandung: Alfabeta

Uno, B. H., (2007). Teori Motivasi dan Pengukurannya. Jakarta: Bumi Aksara 